\title{
Semiotics Analysis on Students' English Textbook in Elementary School
}

\author{
${ }^{* 1}$ Tri Indah Rezeki, ${ }^{2}$ Rakhmat Wahyudin Sagala \\ ${ }^{1}$ STKIP Budidaya Binjai, Indonesia \\ ${ }^{2}$ Universitas Muhammadiyah Sumatera Utara, Indonesia \\ *Correspondence: \\ trindah.rizky@gmail.com
}

Submission History:

Submitted: July 30, 2021

Revised: October 06, 2021

Accepted: October 07, 2021

(c) $\underset{\mathrm{EY}}{\mathrm{C}}$

This article is licensed under a Creative Commons Attribution 4.0 International License.

\begin{abstract}
One of the most important components in teaching-learning activities is textbooks. The author of the textbook must tailor it to the cognitive development of children at a given age. Semiotics is one of the factors that can be examined in a textbook since the illustration of semiotics is a particular feature that substantially influences children's visual perception. The purpose of this research is to examine Semiotics in Elementary School English textbooks. This study applied qualitative research in terms of library research to collect the data from the students' English textbooks in the second-grade Elementary school. Semiotic analysis based on Pierce's semiotic theory, namely representamen (signifier), object (referent), and interpretant, was used to analyze the data (signified). Because the activities contain symbols, pictures, and signs that are extremely engaging for the second-grade students of Elementary school at SDIT Al-Hijrah 2, this study concluded that this book is very suited for learning for the second-grade students of Elementary school at SDIT Al-Hijrah 2. The researchers looked at the most important images relevant to the theme of the activities. In addition, the exercise imagery and meaning are linked to one another.
\end{abstract}

Keywords: Semiotics analysis, students' English textbook, elementary school

\section{INTRODUCTION}

English as a Second Language (ESL) Instructors are aware that language textbooks have a considerable impact on students' perceptions of foreign cultures who do not normally encounter English in their daily lives (Rashidi \& Meihami, 2016). Language textbooks are perfect for promoting cultural and global citizenship ideas, as well as serving as cultural tools and artefacts (Gray, 2000). Educators and policymakers create realistic 
and informative textbooks and curricula, and textbooks must encourage students to participate in our fascinating and diverse cultures (Davidson \& Liu, 2020). Language, on the other hand, is critical in social phenomena in which people can communicate their experiences through language. Wishes, hopes, feelings, orders, and statements of reality are all expressed in this language. As a result, language's principal function is as a means of communication (Malyuga \& Orlova, 2017). Humans are meaningless without language, and language is regarded as the most important means of communication for conveying meaning (Rezeki \& others, 2018). Surprisingly, one aspect of language meaning is linked to word choices and how they are communicated. As a result, when a speaker is unable to deliver his or her point in one language, the speaker must switch to a more understandable language (Sagala, 2018). Many experts have claimed in the past that a language is a tool for interacting or communicating and that it may be used to express thoughts, ideas, concepts, or even emotions. As a result, language has a long history as a means for conveying ideas. However, because language is fundamentally about communication, a sociolinguistic theory is more limited "Who is it that is speaking? What is the language? To whom are you writing? When are you going to do it, and why are you going to do it?" As a result, language functions such as speakers, listeners, subjects, codes, and discourse can be viewed from a sociolinguistic perspective from a variety of angles (Kleyn \& Garcia, 2019).

A prior study looked at two supporting components for language: the sign or symbol and the language's sound (Aragno, 2019). In the formation and arrangement of a language, both of these forces interact. Anything can be a sign as long as we understand it to mean something, according to the definition. Semiotics is the study of how meaning is represented in a variety of settings, most notably in text and media (Chandler, 1994). A symbol is an arbitrary and customary representation of a signifier and signified connection. Users determine the meaning of symbols, which can vary from one location to the next since symbols can take the shape of an alphabetical letter, punctuation marks, words, phrases, sentences, numbers, Morse code, traffic light, and the national flag (Stojiljković \& Ristić Trajković, 2018). Furthermore, while signs and symbols have the same meaning, they are utilized differently (Stokoe \& others, 2019). It happened because the connections between these two items are tenuous, and the subjects' limitations are near. The focus of this research was on the language sign or symbol depicted in an English textbook.

Semiotics is the branch of linguistics that deals with signs and symbols. The study of sign systems and how they are used is known as semiotics (Eco, 1979 \& Fawcett, 2015). The content and expression plane, or meaning and expression, are the two elements that makeup semiotics. Semiotics, on the other hand, is divided into general and specific branches (Krogstie, 2002), with the study of language falling under the latter (Chomsky, 1979). The properties of universal semiotics include the two aspects of "meaning" and "expression." Unlike general semiotics, which consists of two elements, language semiotics consists of three elements or strata: "meaning," "shape," and "expression." As an expression, meaning refers to form, which blends form with meaning (functioning as 
meaning). As a result, language is said to be divided into three strata. Semantics, wordings, and sounds are the three elements or strata of language semiotics: meaning, shape, and expression. To put it another way, semantics is based on lexicogrammar, which has a phonological code. As a result, language takes the form of sounds, letters, or signs. The semiotic boundary's object of study is determined by the nature of the sign (Petrilli \& Ponzio, 2016). The writers of this work use Peircean semiotics to understand the world as human lives (Jappy, 2019).

The three fundamental aspects of Peirce's triangle meaning semiotic theory (Saragih, 2013) are representamen (signifier), Interpretant (signified), and object (represent). First, a representamen (signifier) is a tangible object that can be felt by the five human senses and refers to or represents something other than the sign itself. Symbols (signs arising from agreements), Icons (signs arising from physical representatives), and Index, according to Peirce, make up the representamen (signs that arise from a cause-effect relationship). Second, interpretant (signified) is the concept of interpreting a sign to a specific interpretation or significance in someone's mind concerning the thing referred to by a sign. The most important aspect of the semiotics process is how meaning arises from a sign when it is used to communicate. Third, the social context that constitutes the sign's reference or something that the sign refers to is called the object (referent).

In some disciplines, semiotics can be realized. One of them is in the field of education. There is educational interaction communication between the teacher and the students during the teaching-learning process. Infrastructure, such as learning media, is required for this type of training. Anything that may be utilized to communicate messages from sender to receiver in order to stimulate students' ideas, feelings, attention, and interests in such a way that the learning process occurs is referred to as learning media (Fuady \& Mutalib, 2018). As a result, the use of the surrounding environment and electronic equipment should be utilized when it comes to learning material.

Textbooks are prevalent in school life, such as reliance, relying on, and closely following (Britton et al., 1993). A textbook can be defined as a standard source of information for a formal study of a subject as well as a teaching-learning device (Graves \& $\mathrm{Xu}, 2000)$. It has been one of the many resources available to teachers for planning an effective class and providing a framework for guiding and orientation. Furthermore, the textbook gives a novice teacher confidence and assurance when it comes to altering current textbooks, especially for customised work-related courses.

It's important to note that no one-size-fits-all textbook will ever be perfect for any language program. There is no such thing as an ideal textbook for every teacher, every set of students, or every teaching environment. Furthermore, teachers' reactions to adopting ready-made textbooks are varied. Many teachers are forced to utilize textbooks and are obligated to use them in their current form. Because this makes class preparation easier for teachers, it is acceptable for some teachers who eventually become overly reliant on textbooks and opt to stick to the text strictly, making only minor adjustments and 
additions. Some teachers, on the other hand, disagree with the textbook's approach to learning and want to make significant modifications to the textbook they must use.

The textbook is one of the most essential forms of interaction with the language for the students. It's a framework or guide that aids students in organizing their learning. It is beneficial to involve students in the process of textbook adaptation. As a result, students will feel that their needs are being met, and they will be much more driven to complete their studies (Graves \& Xu, 2000).

Symbols or graphics are now used by numerous publishers to publish textbooks. Elementary school students, particularly those in Grade II, have a proclivity for imagining what is going on around them, including the teaching and learning process. In fact, pictures or symbols in textbooks are frequently utilized to excite students' imaginations so that the content, particularly foreign teaching materials such as English, Arabic, and others, are easier to comprehend. The focus of this study was on the students' English textbook in Grade II Elementary School, which contains a lot of symbols and illustrations, particularly in the activities.

In keeping with this, the Minister of National Education outlined the requirements for good textbooks, stating that they must be written clearly and understandably. The book must be attractively presented, with photos and descriptions, and the contents must describe something that corresponds to the author's idea.

Many researchers have conducted semiotics study in prior studies. To begin, Hawan (2018) conducted a study on semiotic signs and how their meaning is realized in these movie posters. He discovered that the movie poster contains visual and verbal semiotic signs, often known as pictures and written language. He also discovered that the semiotic sign is realized through the triadic semiosis' parts of representamen, object, and interpretant. Second, (Prasojowati et al., 2019) looked at a semiotic analysis on a cigarette package. According to the experts, visual images are semiotic signs that have successfully delivered messages to the person who viewed them and are understandable enough to be interpreted by the addressee. Third, (Gandhi, n.d.) conducted a study on the semiotics of Ruang Guru advertising on television. Ruang Guru employed indicators that indicated outstanding features to entice television viewers, he concluded. Animated instructional films, practice questions, debate, and application-based learning are some of the highlights. Fourth, (Robingah, 2020) studied Peirce's Semiotics Analysis on Benny's Cartoons concerning Covid 19 issues. He discovered that the purpose of releasing Benny's cartoon is to provide people with a sense of humor; it is not to criticize or satirize the government, but rather to depict how people live in the midst of the corona virus outbreak. In addition, a study on Representation of Social Class in Film: Semiotic Analysis of Roland Barthes Film Parasite, was conducted by (Dianiya, 2020). It was discovered that while films are not included in the logic of most cultural sectors, they nonetheless succeed in accessing the international market and that there are at least five major factors to consider: ease of living, 
fashion, limits, body odor, and color. As a result, the film Parasite's depiction of social class is flawless in terms of scenes, properties, and cinematography.

Based on this phenomenon, the researchers are motivated to conduct this research in the hopes that the findings would assist instructors, students, parents, and authorities in identifying and developing good textbooks for use in the teaching and learning process. As a result, the study's problems are centered on recognizing the meanings of semiotics in students' English textbooks in Grade II Elementary school and examining how semiotics are realized in students' English textbooks in Grade II Elementary school.

\section{METHOD}

\section{Research design}

The writers used a qualitative approach to transmit data in descriptive forms, such as people's words or statements, texts, or other languages (Taylor et al., 2015). This study used content analysis to explain the contents of the English textbook as well as the process of obtaining the source documents, resulting in detailed results (Krippendorff, 2018). The content analysis factual principle is limited to the message's apparent content, not the researcher's viewpoint (Wimmer \& Dominick, 2009).

\section{Research site}

The students' English textbooks, "Basic English For Elementary School Second Edition," provided the study's data. The information was gathered from the book's exercises, which all include symbols or drawings. Numbers, timings, adjectives, activities, days and months, prepositions, places, and colors were among the eight data items examined using semiotic theory.

\section{Data selection}

Because textbooks are respected sources in formal education, the researchers chose an English textbook as the subject (Graves \& Xu, 2000). The author of the book uses a combination of visuals and prose to explain each topic (Basturkmen, 2010). Meanwhile, the book's illustrations attract students' attention when they are learning English, and the visuals are part of the semiotic system (Eco, 1979 \& Fawcett, 2015). Furthermore, the book's contents are packaged using symbols that are pertinent to the subject that may be studied using semiotics (Saragih, 2013).

\section{Data collection}

Because the data sources in this study are documents or written data, the data were obtained using documentation techniques and evaluated using content analysis (text). Documentation, in this case, refers to public and private records obtained by qualitative scientists about a location or study participants (Cohen et al., 2007). The semiotic meaning embedded in the visual picture of the Grade II English textbook "Basic English for Elementary School Second Edition" was documented in this study. 


\section{RESULT}

\section{Peirce's Semiotic Meaning Embedded in English Textbook}

The researchers give a semiotics analysis of students' English textbooks in elementary school in the current study (Peirce, 1991). The triadic meaning theory, according to Peirce, comprises of three major elements: representamen (signifier), interpretant (signified), and object (represent). The researchers photographed the activities in English textbooks that used visuals or symbols.

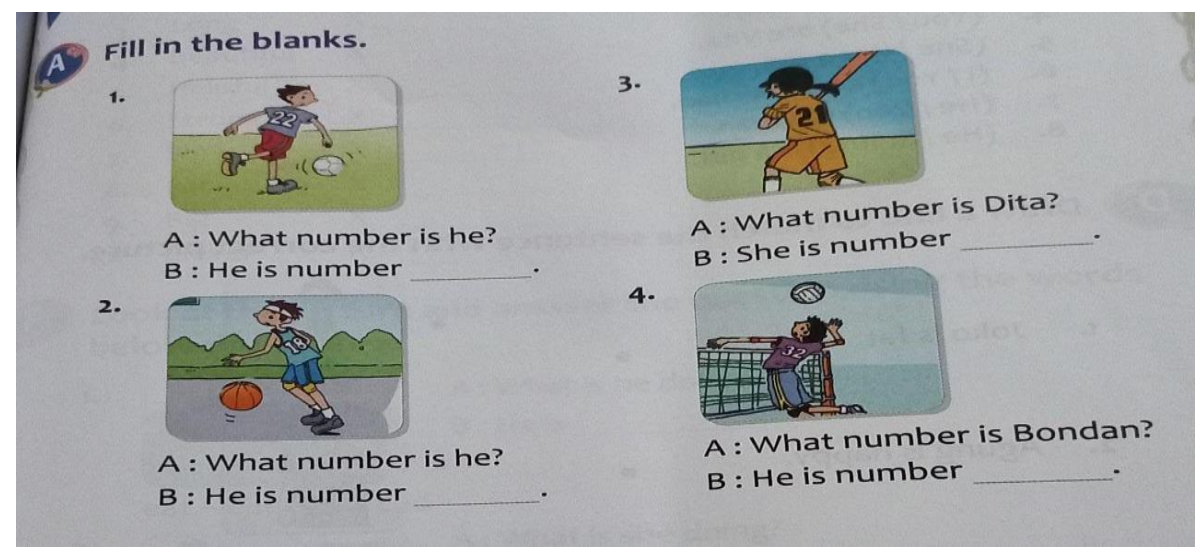

Figure 1. A panel from Page 59 Section A from Basic English for Elementary School Second Edition (2016)

According to Peirce (1991), the representamen (signifier) in Figure 1 consists of Symbols (signs arising from agreements), Icons (signs arising from physical representatives), and Index (signs that arise from a cause-effect relationship). The photos of human characters wearing a shirt with a number on it are the objects (referent). The topic of the exercise, according to the interpreter, is numbers. The numbers based on the photos are related to the student's instructions to fill in the blanks. Because the photos are simple, such as number 22 in picture 1, number 18 in picture 2, number 21 in picture 3 , and number 32 in picture 4, the pupils are easy to answer.

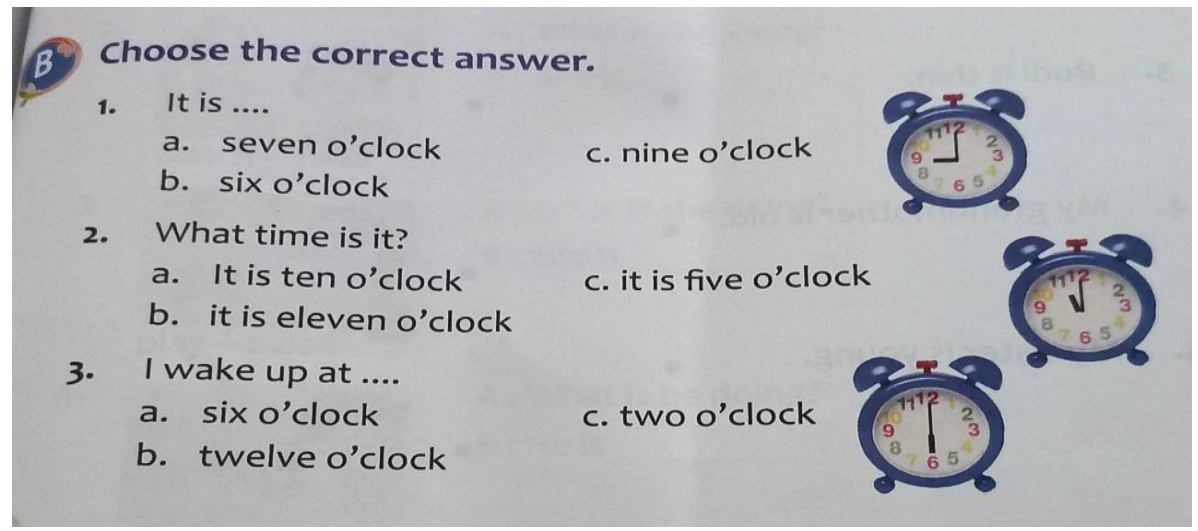

Figure 2. A panel from Page 59 Section B from Basic English for Elementary School Second Edition (2016)

The image of a clock in Figure 2 is the object of semiotic significance. The interpretant is the focus of the number-related exercise. The student's task is to select the 
correct answer that corresponds to the times depicted in the photographs. Because the visuals are simple, such as nine o'clock in picture question 1, eleven o'clock in picture question 2 , and six o'clock in picture question 3 , the kids have an easy time answering.

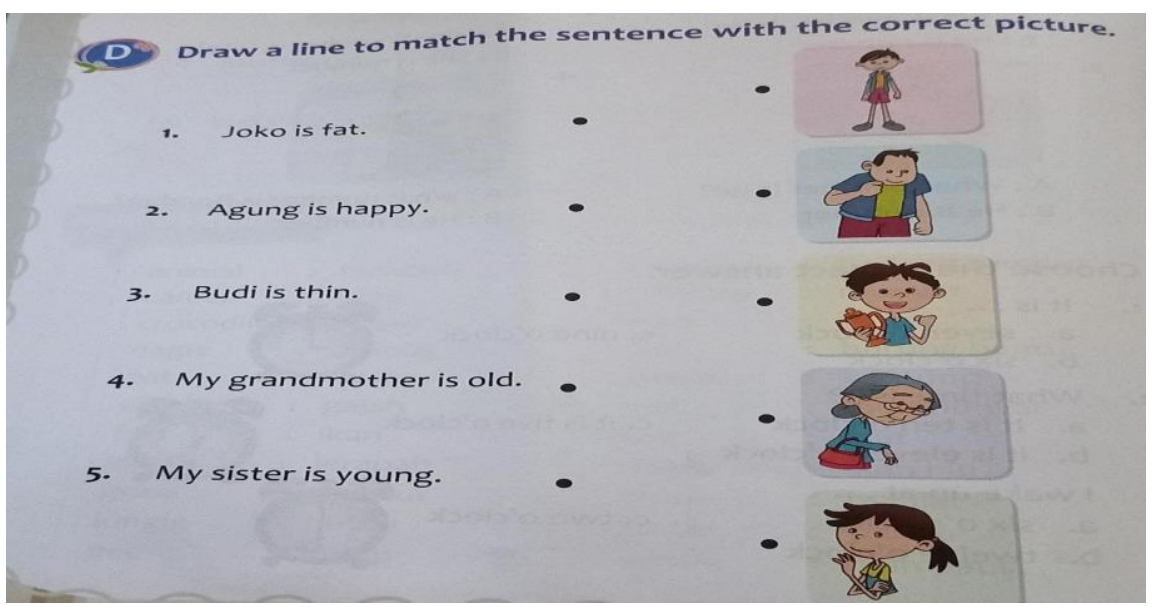

Figure 3. Panel from Page 60 from Basic English for Elementary School Second Edition (2016)

The objects in figure 3 are photographs of humans with various qualities. The interpretant is the focus of the adjectives exercise. Section B's instructions are to draw a line to connect the statement to the appropriate picture connected to the adjectives. Because the photographs are obvious, such as the thin boy in picture 1, the chubby boy in picture 2, joyful boy in picture 3, old grandmother in picture 4, and little sister in picture 5 , the pupils are easy to answer.

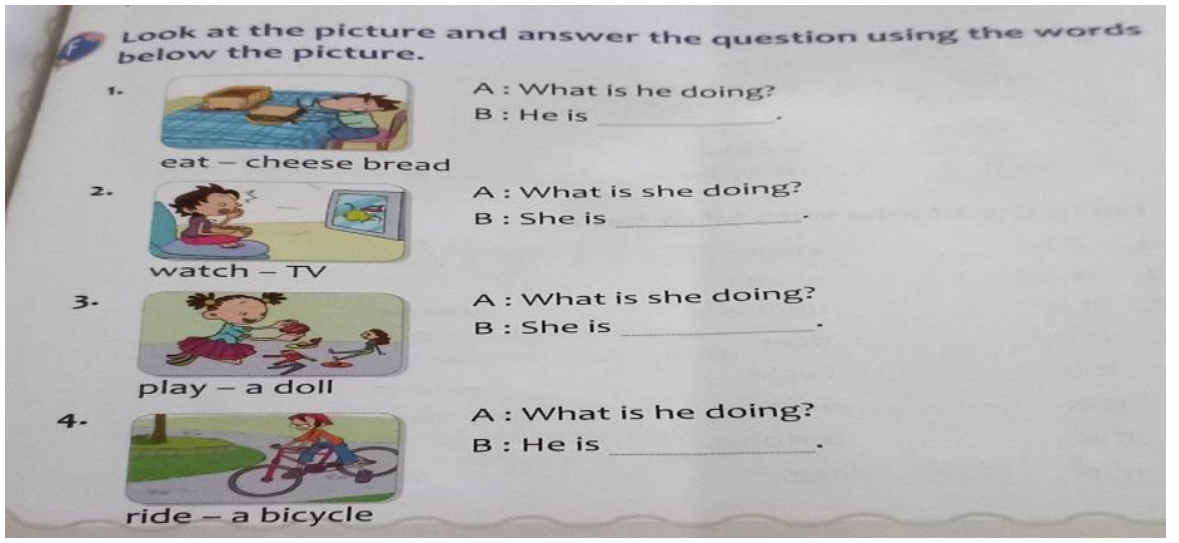

Figure 4. Panel from Page 61 from Basic English for Elementary School Second Edition (2016)

The objects in figure 4 are photographs of people engaged in various activities. The exercise's theme is activities. The pupils are told to look at the photographs and respond to the questions using the terms associated with the activity. Because the photographs are simple, such as eating cheese bread in picture 1, watching TV in picture 2, playing a doll in picture 3 , and riding a bicycle in picture 5 , the pupils are easy to answer. 


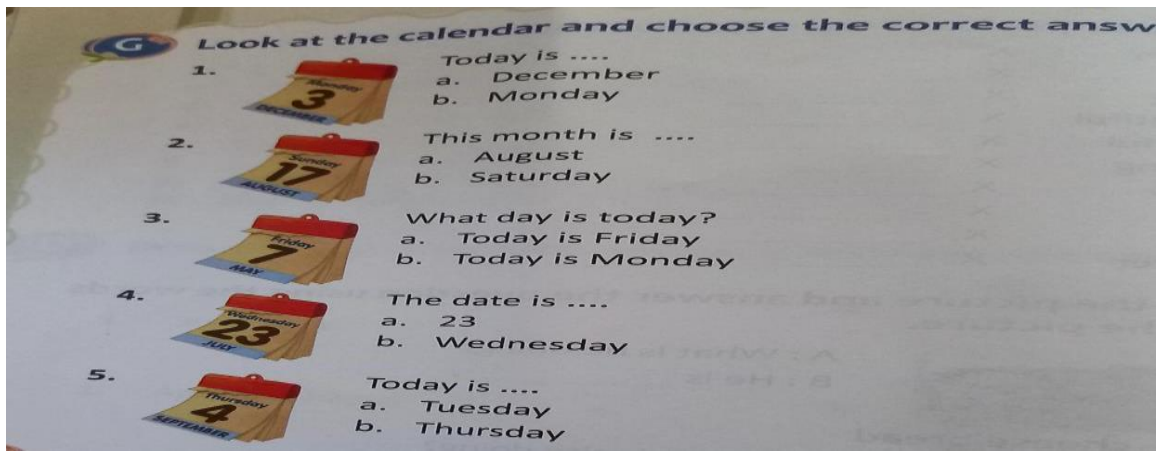

Figure 5. Panel from Page 62 from Basic English for Elementary School Second Edition (2016)

The objects in figure 5 are images of calendars. The exercise revolves around the concept of days and months. The student's task is to examine the calendar and select the appropriate answer for the date, day, and month. Because the pictures are simple, such as Monday in picture 1, August in picture 2, Friday in picture 3, the 23rd of July in picture 4, and Thursday in picture 5 , the kids are easy to answer.

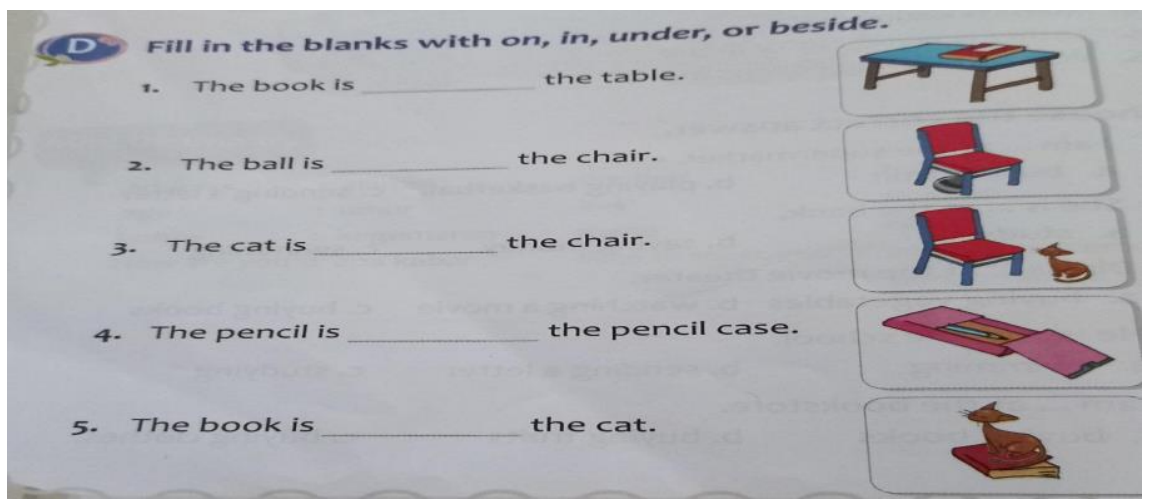

Figure 6. Panel from Page 120 from Basic English for Elementary School Second Edition (2016)

The objects in figure 6 are images of where things are located. Prepositions are the subject of the practice. The pupils are taught to use prepositions to fill in the blanks depending on the photographs. Because the photos are clear, such as the book on the table in picture 1 , the ball beneath the chair in picture 2 , the cat alongside the chair in picture 3 , the pencil in the pencil case in picture 4 , and the book under the cat in picture 5 , the students find it easy to respond.

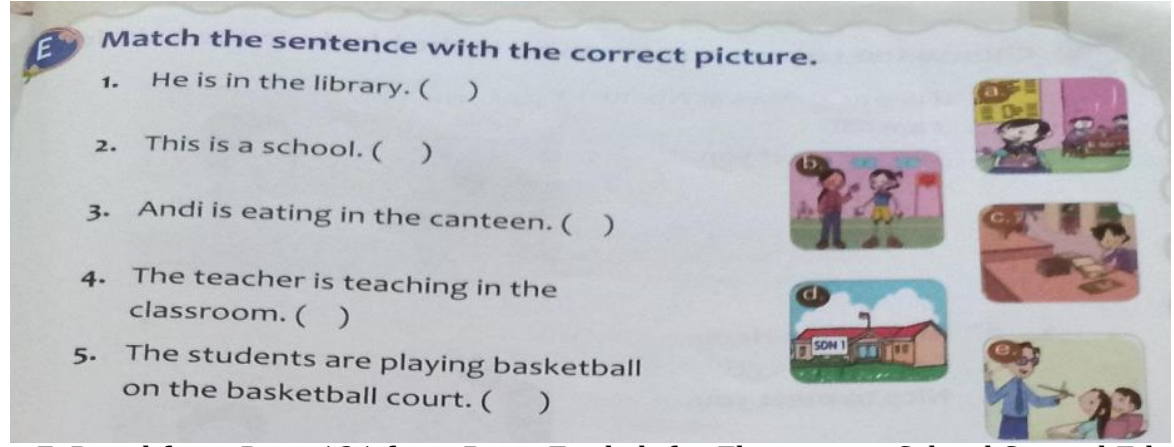

Figure 7. Panel from Page 121 from Basic English for Elementary School Second Edition (2016) 
The objects in figure 7 are pictures of places. The exercise's theme is placed. The students are given the task of matching the sentences to the locales depicted in the photos. Because the photographs are obvious, such as the canteen in picture 1, the basketball court in picture 2 , the library in picture 3 , the school in picture 4 , and the classroom in picture 5 , the students are simple to respond.

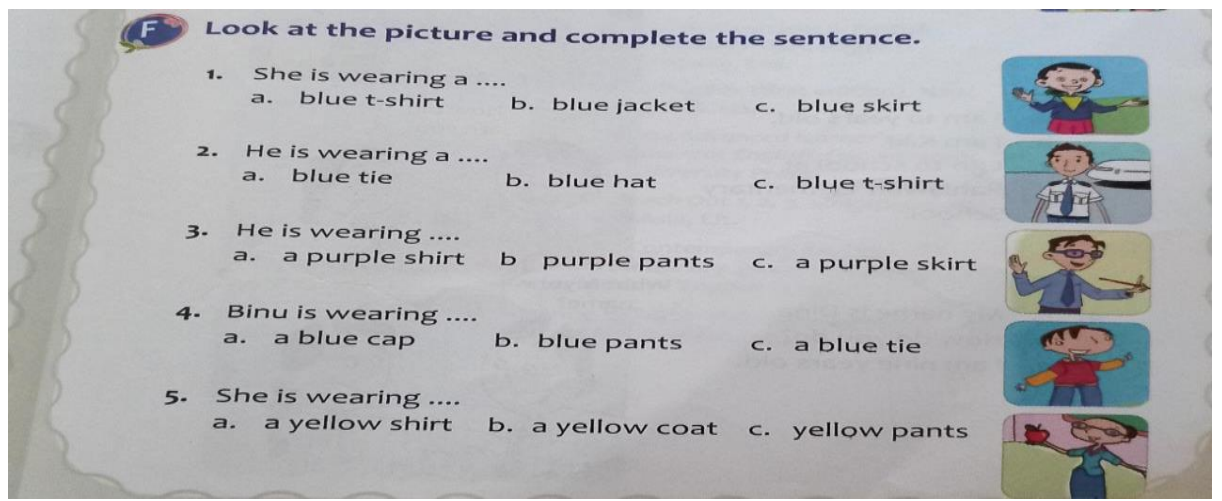

Figure 8.Panel from Page 121 from Basic English for Elementary School Second Edition (2016)

Finally, the objects in figure 8 are photographs of people dressed in various colors. Colors are the focus of the activity. Students are advised to look at the picture and construct the sentence using the pictures as a guide. Because the photographs are obvious, such as a blue jacket in picture 1 , a blue tie in picture 2 , a purple shirt in picture 3 , blue pants in picture 4 , and a yellow shirt in picture 5 , the students are easy to respond.

\section{DISCUSSIONS}

The use of semiotic studies to analyze verbal text is a breakthrough in exposing symptoms that result from text messaging. Static texts could only be usually read by agreement, and it has been determined that the text itself has an expression in communicating its significance (Noth, 1990). Signs in the text can be interpreted in a variety of ways and have a wide range of meanings, depending on the reader's perspective while evaluating the text of the work under consideration. The goal of this study was to see how semiotics were represented in English textbooks for Grade II students in primary school. The findings are the semiotic meaning embedded in English textbooks in order to transmit each book's material. As a result, students are enthusiastic about learning English, which is a foreign language. The researchers conducted open interviews with English teachers in order to learn more about the value of using elementary school English textbooks.

The English textbook for Grade II elementary school pupils is the major data source for this study. In addition, textbooks are required English language textbooks in the integrated Islamic elementary school Al-Hijrah 2 Deli Serdang, North Sumatera. Secondary data sources, on the other hand, complement primary data sources and are pertinent to the research debate. Books on semiotics, Peirce's semiotics theory, and textbooks as learning media are examples of secondary data. The implied meaning of de Saussure's (2011) term 
is that semiotics heavily relies on the rules or social conventions that apply in society in order for signs to be collectively interpreted. The investigation of meaning realization in a Peirce (1991) motivated English textbook reveals three semiotic aspects. These three aspects were determined by data analysis using photographs from the kids' English textbook, "Basic English for Elementary School, Grade II." In addition, eight photographs were captured and examined using Peirce's triadic meaning, after which they were categorised by representamen, interpretant, and object.

Peirce's triadic meaning was examined after the photographs were collected. The representation begins with an image taken from a textbook in the form of symbols, icons, and indexes. According to Peirce, a representamen (signifier) is something in the form that human senses may feel or that symbolizes something other than the sign itself. Second, the interpretant (signified) is the concept of people's thoughts as they use and interpret signs. As shown in Figure 1, the interpreter learned that the concept from the readers' thoughts, which is referred to by a sign, is referred to by a sign. The semiotic process appeared in this case, where meaning comes from a sign when speaking. Finally, the object in Figure 1 is realized as a human character with a shirt number, making it easier for students to write the proper answers on the question page as readers.

\section{CONCLUSION}

After collecting and evaluating data on semiotics analysis in primary school students' English textbooks, it can be determined that semiotics analysis based on Pierce's theory may be interpreted in second-grade students' English textbooks. Based on the data analysis, this study is necessary to be completed as a reference for teachers who will not only use the English textbook but also the graphics or symbols and the book material. The use of semiotics in the second-grade English textbook might be a consideration for primary school teachers so that they can employ teaching media such as textbooks that contain visuals or symbols that are instructive, informative, and make it simpler for students to absorb the subject.

\section{Acknowledgments}

We express our gratitude to the Ministry of Education and Culture of Research and Technology, the Ministry of Research and Technology / National Research and Innovation Agency, Deputy for Strengthening Research and Development who has provided research funding assistance.

\section{REFERENCES}

Aragno, A. (2019). Semiotic realms: Codes, language, mind. A psychoanalytic perspective. Biosystems, 182, 21-29.

Basturkmen, H. (2010). Developing courses in english for specific purposes. Springer.

Britton, B. K., Binkley, M., Woodward, A., \& Binkley, M. R. (1993). Learning from Textbooks: Theory and Practice. Psychology Press. 
Chandler, D. (1994). Semiotics for beginners. daniel chandler [Aberystwyth, Wales?].

Chomsky, N. (1979). Human language and other semiotic systems.

Cohen, L., Manion, L., \& Marrison, K. (2007). Research method in education.[e-book].

Davidson, R., \& Liu, Y. (2020). Reaching the world outside: cultural representation and perceptions of global citizenship in Japanese elementary school English textbooks. Language, Culture and Curriculum, 33(1), 32-49.

de Saussure, L. (2011). Discourse analysis, cognition and evidentials. Discourse Studies, $13(6), 781-788$.

Dianiya, V. (2020). Representation of social class in film (Semiotic Analysis of Roland Barthes Film Parasite). Profetik: Jurnal Komunikasi, 13(2), 212-224.

Eco, U. (1979). A theory of semiotics (Vol. 217). Indiana University Press.

Fawcett, R. P. (2015). The semiotics of culture and language: Volume 2: Language and other Semiotic Systems of Culture. Bloomsbury Publishing.

Fuady, R., \& Mutalib, A. A. (2018). Audio-visual media in learning. Journal of K6 Education and Management, 1(2), 1-6.

Gandhi, A. M. (n.d.). Semiotics analysis of ruangguru advertising in television media. Metacommunication: Journal of Communication Studies, 5(2), 104-114.

Graves, K., \& Xu, S. (2000). Designing language courses: a guide for teachers (Issue 428 G7.). Heinle \\& Heinle Boston, MA.

Gray, J. (2000). The ELT coursebook as cultural artefact: how teachers sensor and adapt.

Hawan, M. R. (2018). An analysis of semiotic signs found in movie poster of pirates of the caribbean. Thesis. Medan: Universitas Sumatera Utara.

Jappy, T. (2019). The bloomsbury companion to contemporary peircean semiotics. Bloomsbury Publishing.

Kleyn, T., \& Garc $\backslash \backslash$ ia, O. (2019). Translanguaging as an act of transformation: Restructuring teaching and learning for emergent bilingual students. The Handbook of TESOL in $\mathrm{K}-12,69-82$.

Krippendorff, K. (2018). Content analysis: An introduction to its methodology. Sage publications.

Krogstie, J. (2002). A semiotic approach to quality in requirements specifications. In Organizational Semiotics (pp. 231-249). Springer.

Malyuga, E. N., \& Orlova, S. N. (2017). Linguistic pragmatics of intercultural professional and business communication. Springer.

Noth, W. (1990). Handbook of semiotics. Indiana University Press.

Peirce, C. S. (1991). Peirce on signs: writings on semiotic. UNC Press Books.

Petrilli, S., \& Ponzio, A. (2016). Semiotics unbounded. University of Toronto Press.

Prasojowati, M. W., Natsir, M., \& Ariani, S. (2019). A semiotic analysis found on the cigarette products. Jurnal Ilmu Budaya, 3(1).

Rashidi, N., \& Meihami, H. (2016). Hidden curriculum: An analysis of cultural content of the ELT textbooks in inner, outer, and expanding circle countries. Cogent Education, 3(1), 
1212455.

Rezeki, T. I., \& others. (2018). Kontekstual code switching dalam seminar proposal program studi pendidikan Bahasa Inggris. Jurnal Serunai Bahasa Inggris, 10(2), 1-7.

Robingah, R. (2020). Pierce's semiotics analysis on benny's cartoons related to covid 19 issues. Journal of Language and Literature, 8(1), 86-95.

Sagala, R. W. (2018). Grammtical code switching in the English department proposal seminar. Budapest International Research and Critics in Linguistics and Education (BirLE) Journal, 1(1), 11-14. https://doi.org/10.33258/birle.v1i1.78

Saragih, A. (2013). Semiotik bahasa: tanda, penanda dan petanda dalam bahasa. Universitas Negeri Medan: Program Pascasarjana.

Stojiljković, D., \& Ristić Trajković, J. (2018). Semiotics and urban culture: architectural projections of structuralism in a socialist context. Social Semiotics, 28(3), 330-348.

Stokoe, W. C., \& others. (2019). Classification and description of sign languages. De Gruyter Mouton.

Taylor, S. J., Bogdan, R., \& DeVault, M. (2015). Introduction to qualitative research methods: A Guidebook and Resource. John Wiley\& Sons.

Wimmer, R. D., \& Dominick, J. R. (2009). Research in media effects. Mass Media Research: An Introduction. 9th Ed. Boston: MA: Cenage Learning. 